by Gilbert J. Price

\title{
Plio-Pleistocene Climate and Faunal Change in Central Eastern Australia
}

School of Earth Sciences, The University of Queensland, St. Lucia, QLD 4072, Australia. E-mail: g.price1@uq.edu.au

Understanding the responses of Plio-Pleistocene terrestrial vertebrates to long-term trends in climate change in central eastern Australia has advanced considerably in recent years following the recovery and documentation of a series of remarkable fossil assemblages. The middle Pliocene Chinchilla Local Fauna of SE Queensland preserves a diverse suite of vertebrate taxa suggestive of a paleoenvironment consisting of wetlands, closed wet forest, open woodlands, and grasslands. Local extinctions of numerous arboreal and terrestrial woodland species suggest that significant faunal and habitat reorganization occurred between the Pliocene and Pleistocene, in part, reflecting the expansion of open woodlands and grasslands. Middle Pleistocene deposits in the Mt Etna region of central eastern Queensland contain extensive fossil assemblages of rainforest-adapted vertebrates dated >500-280 ka. Such faunal assemblages show remarkable long-term stability despite being subjected to numerous glacial-interglacial climatic shifts. However, sometime between 280-205 ka, a major faunal turnover/ extinction event occurred, where the previously dominant rainforest-adapted faunas gave way to xeric-adapted forms. Independent paleoclimatic records suggest that this shift was a result of increased climatic variability and weakened northern monsoons. Late Pleistocene deposits of the Darling Downs, SE Queensland, provide an important temporal extension to the Mt Etna region. Recent studies have demonstrated minimally, a three stage extinction of local megafauna (giant land mammals, birds and lizards). Associated radiometric and optical dating indicates that the progressive loss of megafauna from the region was initiated at least $75 \mathrm{kyr}$ before the continental colonisation of humans. The progressive changes in megafaunal community dynamics were most likely driven by intense climatic changes (i.e., increased aridity) associated with the last glacial cycle. The potential role of humans in the final extinctions (posthuman colonisation) is unclear. However, if humans did have a detrimental impact on the last surviving megafauna, it is likely that they simply compounded upon longer-term climate-driven processes. Independent paleoclimate information suggests that Plio-Pleistocene climates were complex beyond glacial-interglacial cyclicity, and hence, faunal responses were similarly complex.

\section{Introduction}

Queensland, Australia, contains numerous, rich and diverse fossil deposits that chart the evolution and emergence of the continent's vertebrate faunas, from the first Carboniferous tetrapods (Parker et al., 2005), through to dinosaurs (Hocknull et al., 2009), and the appearance of the earliest marsupials (Beck et al., 2008). Arguably one of the most significant fossil sites, the Riversleigh World Heritage fossil area of NW Queensland is renowned for its abundance of deposits (>200) that document the evolution of the modern marsupialdominated vertebrate faunas through the mid-late Cenozoic (Archer et al., 2006). Over 200 mammalian species have so far been identified including dasyurids, bandicoots, marsupial 'moles', possums, koalas, wombats, and kangaroos, as well as now-extinct groups such as diprotodontids and marsupial 'lions'. The older late Oligocene and early-mid Miocene fossil assemblages are typically represented by open woodland, through to wet forest and/or rainforest-adapted taxa, whereas the younger Plio-Pleistocene deposits contain more open, arid-adapted forms suggesting continental aridification during and after the late Miocene (Travouillon et al. 2009).

Significantly, Riversleigh is dominated by Miocene deposits of varying ages; the younger Pliocene and Pleistocene fossil record of Riversleigh is thus far known from only two sites, neither of which have been extensively documented (Travouillon et al., 2006). Thus, a firm understanding of faunal responses to more recent episodes of climate change, such as the establishment of glacial-interglacial cyclicity in the latest Cenozoic, remains unclear. Conversely, southern and central eastern Queensland contains numerous vertebrate fossil assemblages that span this critical period. Thus, it is possible to extend the important record from Riversleigh in order to track the emergence of the modern biota in response to Quaternary climatic regimes as well as long-term trends in the aridification of the Australian continent.

Three key sites, the middle Pliocene Chinchilla Local Fauna, middle Pleistocene Mt Etna region, and late Pleistocene Darling Downs faunas (Figure 1), have attracted significant attention in recent years. Each region contains numerous vertebrate faunal assemblages that have been the focus of intensive paleoecological and/or dating 


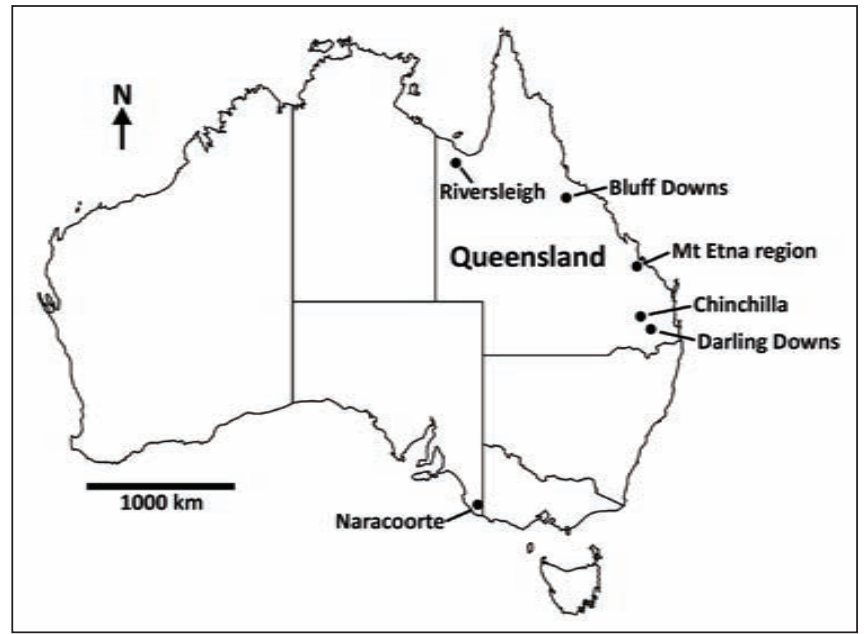

Figure 1 Map of Australia showing major study sites and other mentioned localities.

studies (e.g., Hutchinson and Mackness, 2002; Hocknull, 2005; Price and Webb, 2006; Hocknull et al. 2007; Price et al., 2009a, 2011).

\section{Middle Pliocene Chinchilla Local Fauna}

The Chinchilla Local Fauna, SE Queensland, is derived from the laterally extensive Chinchilla Sand; an extensive sequence of clays, weakly consolidated grey to yellow sands, and ferruginised heterogeneous conglomerates exposed along the Condamine River (Woods, 1960). Strata are dominantly fluviatile in origin, exposed in thin surficial beds and deeply eroded sections (Mackness et al., 2010). The Chinchilla Local Fauna has not been directly dated analytically, however, on the basis of 'stage-of-evolution' and biocorrelation, it may be younger than the early Pliocene Bluff Downs Local Fauna of NE Queensland (Figure 1), but similar in age to the middle Pliocene (c. 3.5 Ma) Kanunka Local Fauna of central Australia (Tedford et al., 1992; Mackness et al. 2000).

Although the Chinchilla Local Fauna is particularly rich, containing a diverse range of taxa including molluscs (gastropods and bivalves), fish, lungfish, turtles, lizards, snakes, crocodiles, and birds (Hutchinson and Mackness, 2002), the mammals have been most intensively studied. The mammals are dominated, in terms of abundance, by large-bodied (i.e., $>40 \mathrm{~kg}$ ) semi-grazing/browsing kangaroos (such species of the extinct Protemnodon), and the grazing Macropus (extant, diverse and widespread across modern Australia). The abundance of grazing forms represents a major shift in dietary niche partitioning of Pliocene faunas from those of older assemblages (e.g., Riversleigh), which are mostly dominated by browsing forms.

Although the preponderance of grazing taxa suggests a dominatingly open paleohabitat, large-bodied browsing kangaroos such as "Simosthenurus", Sthenurus (both short-faced kangaroos of the Sthenurinae) and Troposodon (Lagostrophinae), and diprotodontoids (Palorchestes parvus) have also been recorded from the Chinchilla Sands (Prideaux, 2004). Medium-sized (10-40 kg) forest wallabies (Silvaroo), arboreal tree kangaroos (Bohra) and koalas (Phascolarctos) are also known (Dawson, 2004a, b; Price, 2008a; Price et al., 2009a). Today, tree kangaroos are restricted only to NE Australian and New Guinean tropical rainforests.

Taken together, the paleoenvironmental signal from the Chinchilla fossil vertebrates indicates a significant wetland component, as well as a mosaic of canopies of mature wet forest, possible open woodland, and open grassland (Hutchinson and Mackness, 2002; Price et al., 2009a). However, there remain some limitations on the accuracy of such an interpretation. Although the Chinchilla Local Fauna appears to exhibit exceptional taxic diversity, it is possible that numerous individual, temporally-disparate fossil assemblages have been mixed following collection, such that the 'Local Fauna' is actually significantly time- and habitat-averaged. If that interpretation is correct, existing collections represent at least some temporally disparate forms. Such a hypothesis is presently difficult to test as there is poor stratigraphic control for fossils collected from the region.

\section{Middle Pleistocene Mt Etna region}

The Mt Etna fossil faunas, central eastern Queensland, represent a key temporal extension to not only the Pliocene Chinchilla Local Fauna, but also the older Riversleigh rainforest vertebrate fossil record. Most of the Pleistocene vertebrate fossils collected from the region (Mt Etna and the adjacent Limestone Ridge) represent a series of brecciated cave deposits that formed within Devonian limestones (Figure 2). Bone-yielding sediments are typically well-lithified and contain numerous interlayered datable speleothems (e.g., flowstones, stalagmites, straw stalactites) (Hocknull et al., 2007).

On the basis of biocorrelation, Hocknull (2005) originally considered the fossil faunas to be mostly early Pliocene, with some late Pleistocene and Holocene deposits. However, application of uranium/thorium (U/Th) dating of the speleothems demonstrated that the majority of deposits are in fact middle Pleistocene (Hocknull et al., 2007). Older fossil assemblages may be present in the region as several sites were dated to $>500 \mathrm{ka}$, the chronological application limit of U/Th dating.

The >500-280 ka Mt Etna region fossil faunal assemblages contain a remarkable suite of rainforest-adapted taxa (Hocknull et al., 2007). This is exceptional because they represent the only unequivocal record of Pleistocene rainforest vertebrates on the continent. Moreover, the Mt Etna deposits extend the temporal range of many taxa previously considered to have been pre-Quaternary, into the middle Pleistocene (Hocknull, 2005; Hocknull et al., 2007). Similarly, the deposits are significant in filling in gaps in the fossil record for many extant lineages (Hocknull, 2005).

In terms of diversity, the Mt Etna region assemblages are dominated by small-bodied $(<10 \mathrm{~kg})$ vertebrates, many belonging to forms that are today restricted solely to rainforest environments (cannibal frogs, big-eyed tree frogs, forest dragons, striped possums, cuscuses, tree kangaroos, and white-tailed rodents). The diversity of arboreal mammals is high, with at least four species of tree kangaroo (Dendrolagus spp.), three species of greater gliders (Petauroides spp.), six species of rainforest ringtail possums (Pseudochirops spp. and Pseudochirulus spp.), and two tree rodents (Uromys sp.); each genus is found today either in northern Queensland and/or New Guinean rainforests. Most recently, a new genus and species of koala (Invictokoala monticola) was described from a $320 \mathrm{ka}$ rainforest deposit at Mt Etna (Price and Hocknull, 2011). Identification of a rainforest form is significant because it was previously considered that koalas suffered extinction from such habitats by the late Miocene (Archer and Hand, 1987). Persistence of a vast range of rainforestadapted vertebrates from $>500-280$ ka suggests relative faunal stability through several of the earlier interglacial-glacial cycles that characterised the Quaternary. 


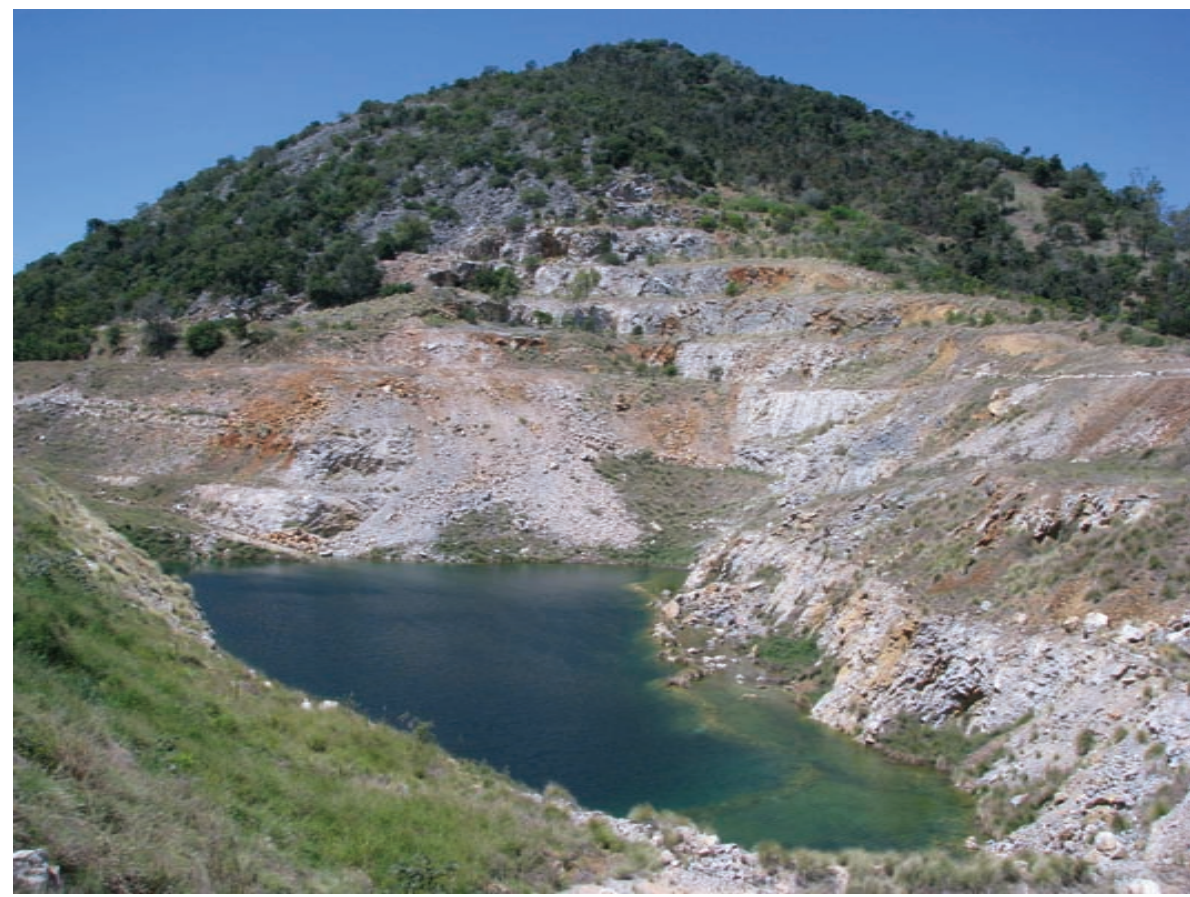

Figure 2 Mt Etna illustrating middle Pleistocene fossil cave breccias (orange-brown sediments), exposed in cross-section as a result of mining activities (September 2008).

Significantly, sometime between 280-205 ka, a major local faunal change occurred in the Mt Etna region where the formally dominant rainforest faunas were replaced by more xeric-adapted forms (e.g., grassland dragons, bilbies, pig-footed bandicoots). The change reflected the loss of $80 \%$ of small to medium-sized mammalian taxa, as well as numerous frog and lizard species. Similarly, approximately $75 \%$ of taxa identified in 205-170 ka deposits have not been recorded from older deposits in the region (Hocknull et al., 2007).

The change in rainforest-adapted, to xeric-adapted, faunas implies a significant reduction in precipitation after $280 \mathrm{ka}$, relative to previous interglacials. Similarly, U/Th dating of speleothems indicates that most grew during interglacials or interstadials, and that nearly $70 \%$ of all dated samples are older than $300 \mathrm{ka}$ (Hocknull et al., 2007). Those data imply that conditions for speleothem genesis (i.e., a wetter environment) were more prevalent prior to $300 \mathrm{ka}$ than after. Other independent paleoclimate data indicate a retraction of the northern monsoon and increased climatic variability after $300 \mathrm{ka}$ (Hocknull et al., 2007).

Another local faunal change occurred in the Mt Etna region sometime after 205-170 ka, reflecting the loss of the xeric-adapted faunas, such that by the Holocene (c. $7 \mathrm{ka}$ ), a more mesic-adapted fauna occurred in the region (similar to today) (Hocknull et al., 2007). This youngest episode of faunal turnover saw an overall decline in species richness with the loss of $65 \%$ of small to medium-sized mammals (Hocknull et al., 2007). Approximately, 38\% of mammals in the post-205-170 ka deposits are not recorded from older deposits in the region (Hocknull et al., 2007). Unfortunately, the late Pleistocene faunal record remains poorly dated. Thus, it is not possible to reliably examine the response of local faunas to climate change associated with the last glacial cycle.

Interestingly, the Naracoorte Caves World Heritage Area of SE South Australia provides a contrasting record of faunal history to that of the Mt Etna region. At Naracoorte, Prideaux et al. (2007) reported a series of middle-late Pleistocene (c. 500-50 ka) faunas from
Cathedral Cave. The data suggest that there was period of marked stability in faunal composition through that time. On the basis of that evidence, Prideaux et al. (2007) argued that climate change prior to human arrival (c. 50-45 ka) was unlikely to be a mitigating factor in the extinction of late Pleistocene megafauna (large bodied terrestrial lizards, birds and mammals). In marked contrast, all megafauna recorded from the middle Pleistocene Mt Etna (marsupial 'lions', diprotodontoids, large-bodied kangaroos) have not been recorded in younger deposits within the region. Thus, the results cannot preclude climate change, in particular, enhanced aridity through the Pleistocene, as a factor involved in the final megafaunal extinctions, at least in northern Australia (Hocknull et al., 2007).

\section{Late Pleistocene Darling Downs}

The eastern Darling Downs, SE Queensland, represents the most extensive deposits of Pleistocene-aged vertebrates on the continent. The deposits are predominately fluviatile in origin, with the sediments derived from erosion of underlying Mesozoic sandstones and mid Cenozoic basalts (Figure 3). Although over 50 distinct fossil sites have been identified in the region (Molnar and Kurz, 1997), the true number of deposits would likely exceed 200 , for every single catchment within the region yields a remarkable number of fossils in abundance. Indeed, the Darling Downs may contain the continent's youngest records of articulated skeletons of now-extinct megafauna (Roberts et al., 2001).

Recent research in the region has focused on the rich Kings Creek catchment deposits of the southern Darling Downs. The Pleistocene Kings Creek represented a series of permanent and ephemeral streams within a geographically small catchment (Price, 2005). The geometry of the paleocatchment precludes long-distance transport of the fossils, thus, resulting paleoecological models should reflect only a local signature. The megafauna-bearing deposits typically represent a series of stacked highly fossiliferous sequences. The deposits reflect both high-velocity lateral accretion (channel) and low-velocity vertical accretion (overbank deposits) (Price and Sobbe, 2005; Price and Webb, 2006).

Vertebrate and invertebrate fossils are more common in the coarser grained high energy deposits than the low velocity vertically accreted sediments. The assemblages are exceptionally diverse, including freshwater and terrestrial gastropods, bivalves, fish, frogs, lizards (skinks, agamids and varanids), snakes, turtles, birds, and small and large mammals (Price, 2002, 2005, 2008b; Price and Hocknull, 2005; Price and Sobbe, 2005, 2011; Price et al., 2005, 2011; Price and Webb, 2006). The megafaunal taxa (e.g., Figure 4) include several forms descended from Pliocene ancestors as represented at Chinchilla (e.g., several species of the grazing Macropus) (Bartholomai, 1975). In most, if not all cases, the derived forms are significantly larger than their Pliocene counterparts, such as the kummerspeck Diprotodon, a 2,700 kg descendent of the more diminutive Pliocene Euryzygoma. The tendency for faunas to trend towards gigantism 


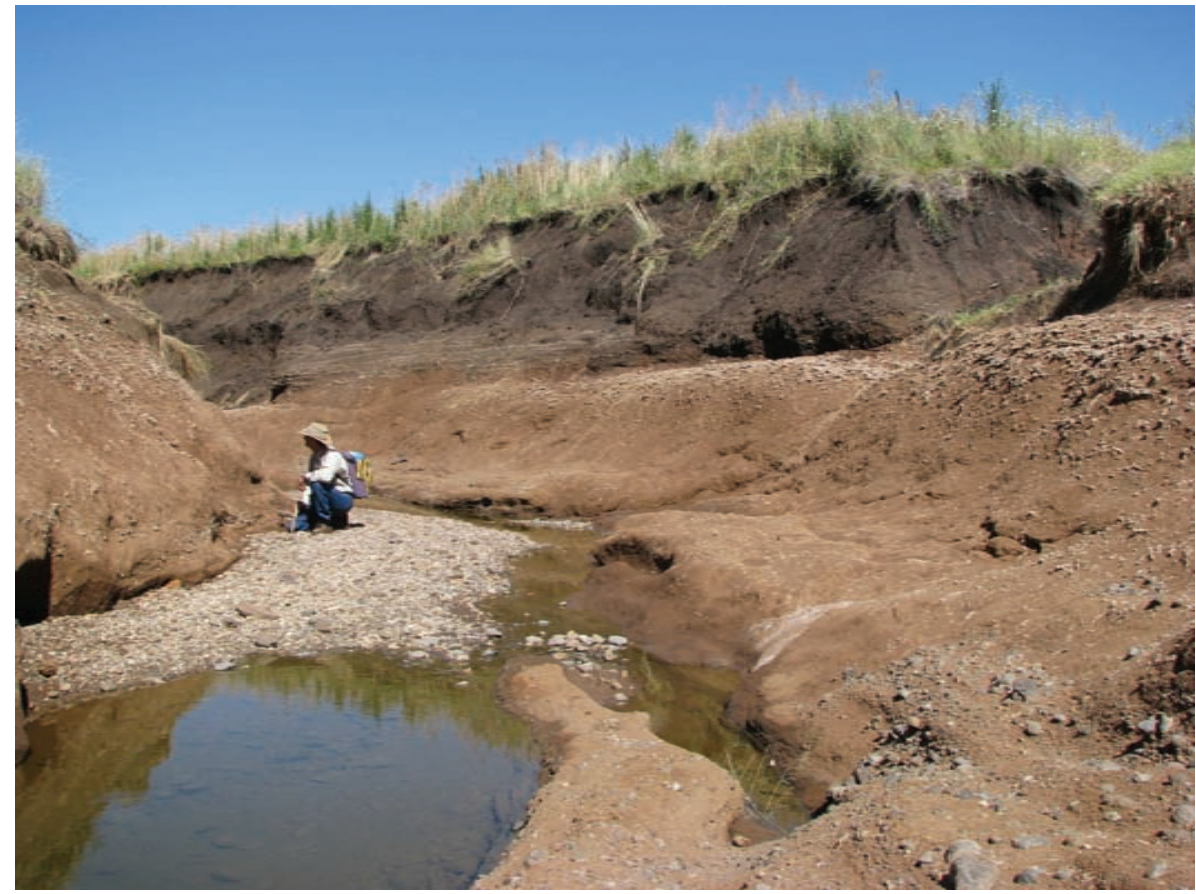

Figure 3 Late Pleistocene megafaunal fossil locality at Neds Gully, Darling Downs, illustrating high-velocity (channel) and low-velocity (overbank, vertical accretion) deposits (January 2011).
Collectively, the Pleistocene assemblages reflect a significantly drier climatic signature than those of the Pliocene Chinchilla Local Fauna. The implication of such an interpretation is that major habitat and faunal reorganisation occurred locally between the Pliocene and Pleistocene, reflecting the expansion of open woodlands and grasslands, and contraction of dense woodlands (Price et al., 2009a).

Recent radiometric (radiocarbon and $\mathrm{U} / \mathrm{Th}$ ) and optical dating has focused on developing reliable chronologies of deposition for the late Pleistocene Darling Downs megafaunal sequences (Price and Sobbe, 2005; Webb et al., 2007; Price et al., 2011). The dates are significant in that they show a long-term decline in local megafaunal community diversity during the period immediately leading up to the hypothesised time of human continental colonisation. Minimally, a three stage local extinction of late Pleistocene megafauna has been identified (Price and Webb, 2006). The data are most parsimoniously consistent with a temporally over the Plio-Pleistocene may be a result of physiological responses to changes in the physical and/or biotic environment (Price and Piper, 2009).

Overall, the Pleistocene faunas differ significantly in composition from the older proximal Pliocene Chinchilla Local Fauna. Strictly arboreal forms, such as tree kangaroos (e.g., Bohra from Chinchilla), have not been reported from the younger Pleistocene Darling Downs deposits, nor the adjacent Texas Caves and Gore deposits (Price et al., 2009b). The Pleistocene deposits also lack the diverse small browsing forest wallabies (Silvaroo and related forms) characteristic of the Pliocene at Chinchilla. Crocodiles are much rarer elements of the Pleistocene deposits in comparison to Chinchilla. Proportionately, the Pleistocene faunas are composed of a greater number of grazing taxa and other mixed feeders that are typical of open habitats.

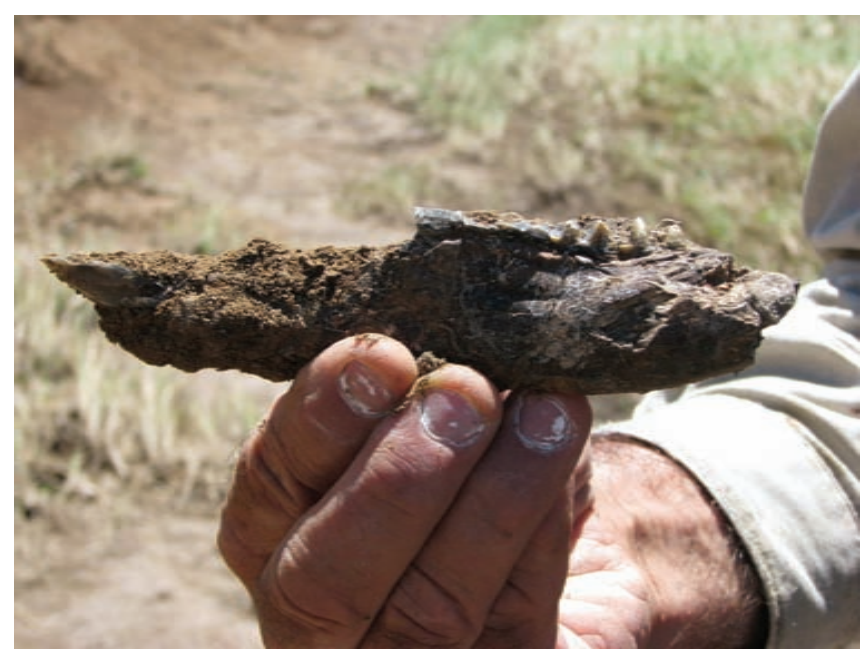

Figure 4 Lower left dentary of a giant forest wallaby, Protemnodon, from a late Pleistocene megafaunal fossil locality at Kings Creek, Darling Downs (January 2011). progressive, pre-human climate change model of megafaunal extinction. Other paleoecological information, gleaned from nonmegafaunal taxa, suggests a long-term trend towards increasingly open, arid environments over the period of deposition (Price, 2005; Price et al., 2005; Price and Webb, 2006). Collectively, the data are not consistent with a nearly simultaneous extinction of megafauna as required for supporting the human-induced blitzkrieg overkill extinction hypothesis (Price et al., 2011). The results do not necessarily reject the overkill hypothesis for the later surviving forms, such as Macropus giganteus titan (giant grey kangaroo) and Diprotodon optatum recorded from the youngest megafaunal site at Neds Gully (dated to $46 \pm 7$ ka by Roberts et al. 2001). However, a current lack of younger, dated local sites does not allow for examination of extinction dynamics post-deposition of Neds Gully. It should also be noted that evidence for human-megafaunal interaction is lacking and that the oldest archeological record of humans locally post-date the youngest megafauna deposits by more than $30 \mathrm{kyr}$ (Gill, 1978).

\section{Conclusions}

Central eastern Australian vertebrate fossil deposits preserve evidence for long-term faunal change and attenuation in response to progressively arid climates during the Plio-Pleistocene. The overall trend is towards increasingly open habitat-adapted faunas as a response to the retraction of wet closed woodlands and tropical rainforests, and expansion of grasslands. Independent sedimentological, palynological, and paleontological datasets are beginning to demonstrate that major Quaternary climatic events (e.g., aridification) were temporally asynchronous in different regions of Australia (e.g., central vs coastal; northern vs southern). Thus, because late Quaternary climate changes were complex beyond glacial-interglacial cyclicity, faunal response(s) must have been similarly complex. In terms of understanding key biological events of the Quaternary, such as the extinction of Pleistocene megafauna, refinement and testing of existing 
hypotheses can only be achieved with far more extensive, complete and reliable datasets than is presently available. Crucially, existing datasets need to be better developed and contain regionally extensive, diverse and especially, well-dated faunal records, coupled with firm stratigraphic control. Regardless, the windows on Plio-Pleistocene Australian paleoclimate, paleohabitats and vertebrate assemblages afforded by Chinchilla, Mount Etna and the Darling Downs provide an exciting glimpse into Australia's recent past.

\section{Acknowledgements}

I thank Ian Sobbe and family, Cec and Doris Wilkinson, Noel Sands and family, Trevor Sutton, and Capricorn Caves tourist park for access and support at the major field sites, as well as Gregory Webb, Jian-xin Zhao, Yue-xing Feng, Scott Hocknull, Alex Cook, and Linda Deer for helpful discussions that improved this paper. I wish to also thank Karen Black and Julien Louys for their constructive reviews, as well as Peter Jell and Keith Scott for editorial assistance. This research was funded in part by the Ian Potter Foundation, Australian Research Council (ARC) Discovery Grants (DP0881279 \& DP120101752), an ARC Discovery Early Career Researcher Award (DE120101533) and ARC Linkage Grants (LP0453664 \&LP0989969), with support from key Industry Partners including Cement Australia, Central Queensland Speleological Society, Rockhampton Regional Development, Riversleigh Interpretative Centre, Xstrata Copper, Queensland Museum, Outback at Isa and Mt Isa City Council.

\section{References}

Archer, M., Arena, D.A., Bassarova, M., Beck, R.M.D., Black, K., Boles, W.E., Brewer, P., Cooke, B.N., Crosby, K., Gillespie, A., Godthelp, H., Hand, S.J., Kear, B.P., Louys, J., Morrell, A., Muirhead, J., Roberts, K.K., Scanlon, J.D., Travouillon, K. and Wroe, S., 2006, Current status of species-level representation in faunas from selected fossil localities in the Riversleigh World Heritage Area, northwestern Queensland: Alcheringa, Special Issue, v. 1, pp. 1-17.

Archer, M. and Hand, S.J., 1987, Evolutionary considerations, in Cronin, L. (ed), Koala: Australia's Endearing Marsupial: Reed Books, Sydney, pp. 79-106.

Bartholomai, A., 1975, The genus Macropus Shaw (Marsupialia; Macropodidae) in the upper Cainozoic deposits of Queensland: Queensland Museum, Memoirs, v. 17, pp. 195-235.

Beck, R.M.D., Godthelp, H., Weisbecker, V., Archer, M. and Hand, S.J., 2008, Australia's oldest marsupial fossils and their biogeographical implications: PLoS ONE, v. 3, pp. e1858.

Dawson, L., 2004a, A new fossil genus of forest wallaby (Marsupialia, Macropodine) and a review of Protemnodon from eastern Australia and New Guinea: Alcheringa, v. 28, pp. 275-290.

Dawson, L., 2004b, A new species of tree kangaroo (Marsupialia, Macropodinae) from the Pliocene Chinchilla Local Fauna: Alcheringa, v. 28, pp. 267-273.

Gill, E.D., 1978, Geology of the late Pleistocene Talgai cranium from S.E. Queensland, Australia: Archaeology and Physical Anthropology in Oceania, v. 13, pp. 177-197.

Hocknull, S.A., 2005, Ecological succession during the late Cainozoic of central eastern Queensland: Extinction of a diverse rainforest community: Queensland Museum, Memoirs, v. 51, pp. 39-122.

Hocknull, S.A., Zhao, J.-X., Feng, Y.-X. and Webb, G.E., 2007, Responses of Quaternary rainforest vertebrates to climate change in Australia: Earth and Planetary Science Letters, v. 264, pp. 317-331.
Hocknull, S.A., White, M.A., Tischler, T.R., Cook, A.G., Calleja, N.D., Sloan, T. and Elliott, D.A., 2009, New Mid-Cretaceous (Latest Albian) Dinosaurs from Winton, Queensland, Australia: PLoS ONE, v. 4, pp. e6190.

Hutchinson, M.N. and Mackness, B.S., 2002, Fossil lizards from the Pliocene Chinchilla Local Fauna, Queensland, with a description of a new species: South Australian Museum, Records, v. 35, pp. 169-184.

Mackness, B.S., Whitehead, P.W. and McNamara, G.C., 2000, New potassiumargon basalt date in relation to the Pliocene Bluff Downs Local Fauna, northern Australia. Australian Journal of Earth Sciences, v. 47, pp. 807811.

Mackness, B.S., Cooper, J.E., Wilkinson, C. and Wilkinson, D., 2010, Palaeopathology of a crocodile femur from the Pliocene of eastern Australia: Alcheringa, v. 34, pp. 515-521.

Molnar, R.E. and Kurz, C., 1997, The distribution of Pleistocene vertebrates on the eastern Darling Downs, based on the Queensland Museum collections: Linnean Society of New South Wales, Proceedings, v. 117, pp. 107-134.

Parker, K., Warren, A. and Johanson, Z., 2005, Strepsodus (Rhizodontida, Sarcopterygii) pectoral elements from the Lower Carboniferous Ducabrook Formation, Queensland: Journal of Vertebrate Paleontology, v. 25 , pp. $46-62$.

Price, G.J., 2002, Perameles sobbei sp. nov. (Marsupialia, Peramelidae), a Pleistocene bandicoot from the Darling Downs, south-eastern Queensland: Queensland Museum, Memoirs, v. 48, pp. 193-197.

Price, G.J., 2005, Fossil bandicoots (Marsupialia, Peramelidae) and environmental change during the Pleistocene on the Darling Downs, southeastern Queensland, Australia: Journal of Systematic Palaeontology, v. 2, pp. 347-356.

Price, G.J., 2008a, Is the modern koala (Phascolarctos cinereus) a derived dwarf of a Pleistocene giant? Implications for testing megafauna extinction hypotheses: Quaternary Science Reviews, v. 27, pp. 25162521.

Price, G.J., 2008b, Taxonomy and palaeobiology of the largest-ever marsupial, Diprotodon Owen 1838 (Diprotodontidae, Marsupialia): Zoological Journal of the Linnean Society, v. 153, pp. 389-417.

Price, G.J. and Hocknull, S.A., 2005, A small adult Palorchestes (Marsupialia, Palorchestidae) from the Pleistocene of the Darling Downs, southeast Queensland: Queensland Museum, Memoirs, v. 51, p. 202.

Price, G.J. and Hocknull, S.A., 2011, Invictokoala monticola gen. et sp. nov. (Phascolarctidae, Marsupialia), a Pleistocene plesiomorphic koala holdover from Oligocene ancestors: Journal of Systematic Palaeontology, v. 9, pp. 327-335.

Price, G.J. and Piper, K.J., 2009, Gigantism of the Australian Diprotodon Owen 1838 (Marsupialia, Diprotodontoidea) through the Pleistocene: Journal of Quaternary Science, v. 24, pp. 1029-1038.

Price, G.J. and Sobbe, I.H., 2005, Pleistocene palaeoecology and environmental change on the Darling Downs, SE Queensland, Australia: Queensland Museum, Memoirs, v. 51, pp. 171-201.

Price, G.J. and Sobbe, I.H., 2011, Morphological variation within an individual Pleistocene Diprotodon optatum Owen, 1838 (Diprotodontinae; Marsupialia): implications for taxonomy within diprotodontoids: Alcheringa, v. 35, pp. 21-29.

Price, G.J. and Webb, G.E., 2006, Late Pleistocene sedimentology, taphonomy and megafauna extinction on the Darling Downs, southeastern Queensland: Australian Journal of Earth Sciences, v. 53, pp. 947-970.

Price, G.J., Tyler, M.J. and Cooke, B.N., 2005, Pleistocene frogs from the Darling Downs, south-eastern Queensland, and their palaeoenvironmental significance: Alcheringa, v. 29, pp. 171-182.

Price, G.J., Zhao, J.-X., Feng, Y.-x. and Hocknull, S.A., 2009a, New records of Plio-Pleistocene koalas from Australia: palaeoecological and taxonomic implications: Australian Museum, Records, v. 61, pp. 39-48.

Price, G.J., Zhao, J.-X., Feng, Y.-X. and Hocknull, S.A., 2009b, New U/Th ages for Pleistocene megafauna deposits of southeastern Queensland, Australia: Journal of Asian Earth Sciences, v. 34, pp. 190-197.

Price, G.J., Webb, G.E., Zhao, J.-X., Feng, Y.-X., Murray, A.S., Cooke, B.N., Hocknull, S.A. and Sobbe, I.H., 2011, Dating megafaunal extinction on 
the Pleistocene Darling Downs, eastern Australia: the promise and pitfalls of dating as a test of extinction hypotheses: Quaternary Science Reviews, v. 30, pp. 899-914.

Prideaux, G.J., 2004, Systematics and Evolution of the Sthenurine Kangaroos: University of California Publications in Geological Sciences, No. 146. University of California Press.

Prideaux, G.J., Roberts, R.G., Megirian, D., Westaway, K.E., Hellstrom, J.C. and Olley, J.M., 2007, Mammalian responses to Pleistocene climate change in southeastern Australia: Geology, v. 35, pp. 33-36.

Roberts, R.G., Flannery, T.F., Ayliffe, L.K., Yoshida, H., Olley, J.M., Prideaux, G.J., Laslett, G.M., Baynes, A., Smith, M.A., Jones, R. and Smith, B.L., 2001, New ages for the last Australian megafauna: continentwide extinction about 46,000 years ago: Science, v. 292, pp. 18881892.

Tedford, R.H., Wells, R.T. and Barghoorn, S.F., 1992, Tirari Formation and contained faunas, Pliocene of the Lake Eyre Basin, South Australia: The Beagle, Records of the Northern Territory Museum of Arts and Sciences, v. 9, pp. 173-194.

Travouillon, K.J., Archer, M., Hand, S.J. and Godthelp, H., 2006, Multivariate analyses of Cenozoic mammalian faunas from Riversleigh, northwestern Queensland: Alcheringa, v. 30, pp. 323-349.

Travouillon, K.J., Legendre, S., Archer, M. and Hand, S.J., 2009, Palaeoecological analyses of Riversleigh's Oligo-Miocene sites: Implications for Oligo-Miocene climate change in Australia: Palaeogeography, Palaeoclimatology, Palaeoecology, v. 276, pp. 24-37.

Webb, G.E., Price, G.J., Nothdurft, L.D., Deer, L. and Rintoul, L., 2007, Cryptic meteoric diagenesis in freshwater bivalves: Implications for radiocarbon dating: Geology, v. 35, pp. 803-806.

Woods, J.T., 1960, Fossiliferous fluviatile and cave deposits: Journal of the Geological Society of Australia, v. 7, pp. 393-403.

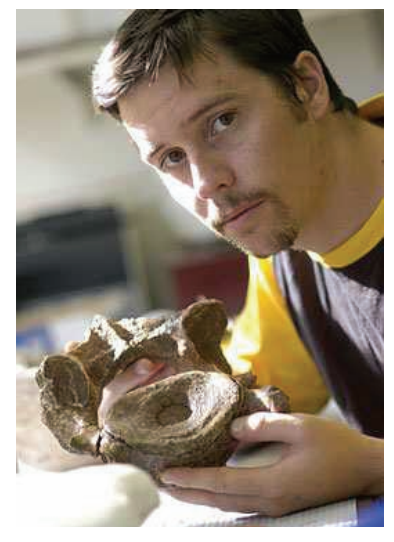

Gilbert Price is a vertebrate paleoecologist and geochronologist, and current Dorothy Hill Postdoctoral Fellow at The University of Queensland, Australia. He is particularly interested in the evolution and emergence of Australia's unique ecosystems and fauna, and their response to prehistoric climatic changes. His major research focus has been on the development of paleoecological models for Australia's Pleistocene megafauna. Critically, this also involves the production of reliablydated records for the extinct forms. 